\title{
EXPRESSIVENESS AND EMOTIONALITY AS LINGUISTIC NOTIONS
}

\section{Melko Kh. B.}

\section{INTRODUCTION}

At the present stage of the development of linguistic science, they increasingly turn to "linguistics of emotions" or "emotiology" as the science of verbalization, expression and communication of emotions. Expressiveness is a component of the connotative component of the semantic structure of a word; a word has an expressive component, if it emphasizes, reinforces what is called an appropriate word; the expressive component is no longer intended to influence the addressee, but to influence the addressee

The concept of linguistic expression is broad and interpreted in linguistics quite generically: "a set of semantic-stylistic features of a language unit that provide its ability to act in a communicative act as a means of subjective expression of the speaker's content or addressee of speech".

Expressiveness is peculiar to units of all levels of language, with lexical expressiveness being expressed at the level of language and speech, and is one of the most productive means, since lexical units carry the main load of verbal expression of the speaker's sensory intension related to the subjective world of subjective evaluation. A word can perform several functions: nominative (noun), generalizable, communicative and expressive (pragmatic). The latter is realized through the transmission of certain feelings, emotions, experiences and evaluations of the speaker and the listener by word.

In modern linguistics, the interest of researchers in the problem of expressiveness is clearly seen, which is connected with the understanding of the diversity of cultural forms of human activity and revealing the deep foundations of human existence. Language is a living multifaceted object that has the ability to constantly change, improve, which can be studied from different perspectives, in different functional, temporal directions. Words in language do not exist in isolation. They are grouped by commonality of values into groups, microsystems. Each word in its microsystem has a specific place, and its meaning is determined by this 
place, because the semantic content of the word is caused by relations that are formed in the grid of oppositions of the given word to other words of the same microsystem.

But despite the great interest in the problem of expressiveness, its general and unanimous theory is absent, which could determine the worldview and linguistic status of this category. Expressiveness is one of the most difficult linguistic categories because it is associated with the manifestation of a subjective beginning in a language that accompanies knowledge of objective reality and reflects the content of the individual consciousness of native speakers of a language.

Language is perceived, recognized and evaluated by a person from an aesthetic point of view. It can also be used by man for aesthetic purposes, or be a means of meeting and architectural aesthetic sense and aesthetic sense recipient. The interest in the problem of expressiveness that has erupted over the last decades is explained by the attention to the linguistic personality, or more precisely, to the description of language as a means of expression and, at the same time, to influence the linguistic personality, its behavior and internal spiritual activity. In expressing his opinion in a linguistic form, the author inevitably expresses his attitude to the subject or situation. Such a message is very often reflected by the sender's subjective attitude to what he or she is talking about or writing about. Expressiveness is seen as a manifestation of the speaker's personality, manifested in the feelings, emotions and evaluations of the subject. This authorial expressiveness is expressed in a language, in a particular choice of linguistic means.

The categories of emotionality and expressiveness are interdependent. Emotional serves to express certain feelings, expressive discharges to enhance the influential power of words. Expressiveness is generated by emotionality, but the concept of expressiveness is broader because it encompasses the aesthetic, normative and evaluative plan. Emotionality is inherent in an internally defined word, expressiveness is adherent, and is acquired by the word in context.

Expressiveness can have an additional effect on the addressee (listener or reader) if the speaker is interested. Thus, expressiveness acts as a phenomenon of linguistic personality and its subjective intentions.

\section{The concept of expressiveness}

Expressiveness is one of the major linguistic problems because it has to do with the emotional attitude of the speaker (or writer) to what is communicated in the speech (in the text). Even official forms of speech, 
such as scientific or business, can be expressive. However, the ways of creating this reflection are varied, ranging from the orientation of speech to a holistic picture of the world, including the imaginative and associative techniques of arousing the emotional attitude of the speaker and the listener, and ending with the expression of the whole palette of feelings in the range of approval / disapproval of what is being said. The main feature of expressivity those cognitive states of the human psyche that encourage "decorate" language, experiencing a certain emotional states. The concept of language expression is quite broad and is understood in modern linguistics in a generalized way. It is "a set of semantic-stylistic features of a language unit that ensure its ability to act in a communicative act as a means of subjectively expressing the speaker's content or content of the speaker," while "expressiveness is characteristic of units at all levels of language."

The notion of expressiveness is one of the basic stylistic, because almost all stylistic paradigms are formed on the opposition (opposition) of expressive and non-expressive. For decades, the phenomenon of expressiveness remains a topical and controversial in linguistic science. The founder of the theory of expressiveness can rightly be considered the French linguist Charles Bally, a representative of the Geneva Linguistic School, which is one of the founders of expressive stylistics. Ch. Bally's concept is a theory of affective language. Charles Bally noted that it is the stylistics that studies the expressive facts of the language system in view of their emotional content and its highest task is to study the expressive system of speech facts ${ }^{1}$.

From $20^{\text {th }}$ century, starting with Charles Bally, the concept of expressiveness was regarded as a stylistic problem. The French linguist proposed to distinguish expressiveness of language from expressiveness of individual speech, while being guided by three main features:

- expressive signs are predefined and do not imply the creative activity of the speaker;

- appropriate techniques and means that create expressiveness have become unconscious to us. We often use them without thinking, their expressive coloring is manifested only in the emotional resonance that accompanies the appearance of expressive signs;

- These signs included in the language and submitting to the law of opposition. In this case, the meaning of the sign is understood not by itself, but by the associations that contrast it with other signs of the system ${ }^{2}$.

\footnotetext{
${ }^{1}$ Fairclough N. Discourse and text: linguistic and intertextual analysis within discourse analysis // Discourse and Society. 1992. № 3. P. 192-217.

${ }^{2}$ Балли Ш. Французская стилистика. Москва: Издательство иностранной литературы, 1961. 393 с.
} 
In the 40's and 60's of the twentieth century, the notion of expressiveness aroused the interest of Karl Vossler, a student of the opponent of Charles Bally. M. Bakhtin was one of the first to pay attention to expression and in his opinion, emotion, evaluation, expression appear only in the course of live language use in a particular expression. If the word is expressive, then this expression belongs not to the word itself, but is born in a real situation ${ }^{3}$. At the end of the twentieth century, there was widespread discussion around the categories of "expressiveness" and "expression" in linguistics. M. Bakhtin's followers gave the following definitions:

- expressiveness is a set of features of linguistic units or expressions / text in which they reflect and indicate the non-neutral attitude of the speaker to the content or addressee of the speech ${ }^{4}$;

- expressiveness is the property of a linguistic sign by virtue of which it is perceived de-automated, directly acting on the imagination of the addressee or his emotional sphere; expressive can be any expression, if it is unforeseen and unexpected ${ }^{5}$;

- expressiveness is the result of pragmatic use of language, which expressing emotional speech current attitude to the subject and marked with "contamination" this attitude of the recipient ${ }^{6}$;

- expression - expressive and pictorial properties of speech that distinguish it from ordinary, stylistically neutral, make speech means emotionally colored ${ }^{7}$.

In the field of linguistic research, there is a tradition of distinguishing between such close concepts as expression and expressiveness. The inaccuracy or non-motivation of using the term "expression", which is defined by linguists as "a set of semantic-stylistic features of a language unit that provide its ability to act in a communicative act as a means of subjectively expressing the speaker's content or content", can lead to some confusion in understanding the very nature of the phenomenon indicated by it. An attempt to elucidate the semantic scope of the term "expressive" in modern linguistics was first made by Wierzbicka A, who compared it with the category of semantic weight, and considered expression itself too

\footnotetext{
${ }^{3}$ Бахтин М. М. Эстетика словесного творчества. М. : Искусство, 1986. 445 с.

${ }^{4}$ Хоменко Г. Є. Експресивні засоби лексико-семантичного рівня інформаційного тексту // Філологічні студії. 2012. № 8. С. 276-282.

${ }^{5}$ Halliday M. A., Hasan R. Language, context and text: aspects of language in a social-semiotic perspective. Oxford: Oxford University Press, 1991. 264 p.

${ }^{6}$ Wierzbicka A. Emotions across languages and cultures: Diversity and universals. Cambridge: Cambridge University Press, 1999. 187 p.

${ }^{7}$ Diller H. J. Emotions and the Linguistics of English. Tuebingen: Niemeier, 1992. 155 p.
} 
broadly, including "emotional", "semantic individuality of assessments", "semantic propaganda". In semantic terms, this category was also considered in the works of V. Kharchenko and V. Shilovsky.

Increased attention of modern linguists to determining the boundaries of expressive has led to the need to distinguish between expressiveness of two types: 1) expressive speech; 2) expressiveness of linguistic units, and accordingly the content of the terms "expression" and "expressiveness". We agree with the opinion of Miller G., who believes that "the intensification of expression of the sign is only in speech (oral or written)" ${ }^{8}$. The linguist explains the inseparability of expression from speech by the fact that in speech the linguistic fabric comes to life, dynamically unfolds and accumulates with additional semantic nuances, where it materializes, gets a specific intonation-emphatic, phonetic, grammatical and stylistic development in accordance with a certain vitality. If expression is expressed only at the speech level, then expressiveness is both speech and speech. Thus, Miller G. clarifies the concept of expressive: "Expression is not something that imparts emotion, imagery, character to speech, but that which is itself generated by emotionality, imagery, and characteristic of speech. Expression is not expressiveness, but an intensification of expressiveness, it is an increase in the striking power of what is said ... ... giving it a special psychologically motivated exaltation". And expressiveness is "this is the most intensified (increased) expressiveness, which maintains the focus of attention, activates the thinking of the person, causes the tension of feelings in the listener or the reader"9.

Expressive theory demonstrates how complex the phenomenon of expressiveness is, and explains the existence of different approaches and concepts of this phenomenon. Expressiveness in the broad sense is nothing but expressiveness, the influence exerted on the sensual sphere of man by some linguistic units. L. Matsko considers expressiveness as semantic and stylistic properties of language units, psychologically and socially motivated, which ensures proper functioning of these units and the creation of stylistic value, background effect"10.

Expressiveness is in speech and language. Speech expressiveness is associated with a purposeful use plan, an upgrade, and the language is associated with an attached connotative feature.

\footnotetext{
${ }^{8}$ Miller G. A. Language and communication. New York: Cambridge University Press, 1951. 214 p.

${ }^{9}$ Лукьянова Н. А. Экспрессивность как семантическая категория / Языковые категории в лексикологии и синтаксисе. Новосибирск, 1991. С. 46-62.

${ }^{10}$ Мацько Л.І. та ін. Стилістика української мови. К.: Вища шк., 2003.
} 
Expressiveness, in the nature and peculiarities of the expression of intensified speech (linguistic), can be incessant and adherent. Inherent expressiveness is the kind of expressiveness that is inherent in a language unit. It is a constant and integral feature of a language element in all conditions and contexts. Adherent expressiveness is acquired or manifested only in a particular speech situation, in a certain context. Context enhances and expresses the semantic structures of expressive words. In fact, any stylistically neutral linguistic element, under certain situational contexts, can express itself intensely.

From a functional point of view, expressiveness is basic (primary) and derivative (secondary). Basic expressiveness is the traditionally established intensified expression of those national and individualauthor formations that are part of the main linguistic and stylistic foundation of the language. Secondary expressiveness is superimposed on the base in connection with some structural and semantic updating of the language.

Expressiveness can have different characters. Intra-personal character is expressiveness that is meaningful only to the person who produces it. Extra-personal character is expressiveness that is created to impress someone. Expressive vocabulary is constantly updated with new words and lexical-semantic variants (including tokens that come from non-Slavic languages), that this language belongs to the lexical active layer.

Expressiveness occurs primarily through evaluative statement that expressed again in the choice of vocabulary. At the heart of expressiveness are different patterns:

1) psychological, which on the one hand, concerning the expression of emotions and feelings on the other hand, their perception;

2) extralingual patterns, the property of the language or text and the communicative situation, that is, the intentions of the speaker or writer, necessary for the communication of knowledge and ideas, as well as the linguistic and linguistic context;

3) linguistic patterns, such as deviations from stereotypes in the use of linguistic units at different levels of language, the inconsistency of linguistic means used with linguistic norms, overcoming possible patterns and standards of sentence structure, and atypical, unusual, expressive sentence construction. ${ }^{11}$

${ }^{11}$ Телия В. Н. Экспрессивность как проявление субъективного фактора в языке и ее прагматическая ориентация / Человеческий фактор в языке. Языковые механизмы экспрессивности. М. : Наука, 1991. С. 5-34. 
Expressiveness serves not only for the effective realization of the intentions of the speaker, but also for the embodiment of his personality in speech. Expressiveness reveals the qualitative side of expression, is a sign of a speech work that is proper and conveys its essence.

Expressiveness, as a result of the use of emotional linguistic units in speech, is an aggregate of semantic-stylistic features that make speech brighter and more diverse. If the statement clearly expresses the subjective-psychological attitude of the person to what she is talking about, then in this situation the emotional or expressive function of speech is realized.

It is distinguished between the expressive and the adherent expressiveness of linguistic units. An expressiveness that is intrinsic to a linguistic sign, is its constant, and is a permanent and integral feature in any contextual context. Adherent expressiveness is the intense expressiveness of a linguistic sign that is formed only in a particular context, situation, conditions, and not in the basic vocabulary. Updating linguistic units according to the speaker's (intention) intent, purpose, situation, conditions makes them expressive, realizing their congruent capabilities, or adding to them adherent (contextual) expression. These units are called expressive means of language. Among the expressive means is genetic, that has long been established, entrenched in the language means as a traditional tropes and figures. They are used by speakers as ready-made expressive forms and as models for producing new ones according to communication needs. Traditional expressive means of speech focus mainly on the lexical (tropes) and syntactic (figures) levels of speech. However, expressiveness as a manifestation of the intensification of the features of linguistic elements is theoretically inherent in all units of language, but is only realized in those linguistic units to which there is such a stylistic inquiry in linguistic practice. Expressiveness is the carrier of the connotation of linguistic units according to the paradigms of stylistic oppositions: positive / negative, good / bad; pleasant / unpleasant, high / low ${ }^{12}$.

Expressiveness may also be achieved by compositional devices in utterances comprising a number of sentences, in syntactical wholes and in paragraphs.

The most powerful expressive means of any language are phonetic. The human voice can indicate subtle nuances of meaning that no other

12 Шаховский В. И. Эмотивный компонент значения и методы его описания. Волгоград : ВГПИ, 1983. - 94 c. 
means can attain. Pitch, melody, stress, pausation, drawling out certain syllables, whispering, a sing-song manner and other ways of using the voice are much more effective than any other means of intensifying an utterance emotionally or logically.

Passing over to some preliminary remarks on the morphological expressive means of the English language, it should be pointed to what is now a rather impoverished set of media to which the quality of expressiveness can be attributed.

Among the word-building means we find a great many forms which serve to make the utterance more expressive by intensifying some of their semantic and/or grammatical properties. The diminutive suffixes -y (-ie), let, e.g. 'dearie', 'sonny', 'auntie', 'streamlet', add some emotional colouring to the words. We may also refer to what are called neologisms and noncewords formed with non-productive suffixes or with Greek roots. Certain affixes have gained such a power of expressiveness that they begin functioning as separate words, absorbing all of the generalizing meaning they attach to different roots, as, for example, 'isms ${ }^{13}$.

At the lexical level there are a great many words which due to their inner expressiveness constitute a special layer. There are words with emotive meaning only (interjections), words which have both referential and emotive meaning (epithets), words which still retain a twofold meaning: denotative and connotative (love, hate, sympathy), words belonging to the layers of slang and vulgar words, or to poetic or archaic layers. The expressive power of these words cannot be doubted, especially when they are compared with the neutral vocabulary.

All kinds of set phrases (phraseological units) generally possess the property of expressiveness. Set phrases, catch words, proverbs, sayings comprise a considerable number of language units which serve to make speech emphatic, mainly from the emotional point of view. Their use in every-day speech is remarkable for the subjective emotional colouring they produce ${ }^{14}$.

It should be noted that due to the generally emotional character of colloquial language, all kinds of set expressions are natural in everyday speech. But when they appear in written texts their expressiveness comes to the fore because written texts are logically directed unless, of course, there is a deliberate attempt to introduce an expressive element in the utterance.

\footnotetext{
${ }^{13}$ Чабаненко В.А. Стилістика експресивних засобів української мови. Запоріжжя: ЗДУ, 2002. 351 с.

${ }^{14}$ Чабаненко В.А. Основи мовної експресії. Київ: Вища школа, 1984. 168 с.
} 
In everyday speech one can often hear such phrases as: "Well, it will only add fuel to the fire" and the like, which in fact is synonymous to the neutral: "It will only make the situation worse".

Finally, at the syntactical level there are many constructions which, when set against synonymous neutral ones, will reveal a certain degree of logical or emotional emphasis.

Stylistics studies the expressive means of language, but from a special angle. It takes into account the modifications of meanings which various expressive means undergo when they are used in different functional styles. Expressive means have a kind of radiating effect. They noticeably colored the whole of the utterance no matter whether they are logical or emotional.

An overview of issues of expressive theory demonstrates how complex the phenomenon of expressiveness is, and explains the existence of different approaches and concepts for the study of this phenomenon.

\section{The notion of Emotionality}

In linguistics, the text considers the language of emotion description and the language of expression of emotions. At the linguistic level, emotions are transformed into emotionality, that is, emotions are a psychological category, and emotionality is linguistics.

People are affected by emotions to various degrees there is a necessity to study the speech behavior of the speaker manifesting his or somebody else's emotional state. Thus, the relevance of the study is due to the fact that the expression of the emotional state of the speaker is of a high social importance and is characterized by the ability to influence the person's activities. Under explicit expression of emotions communicants usually understand what emotion the person expresses or wishes to demonstrate, but there are a lot of speech and non-speech situations when one has to guess about the emotions the interlocutor is experiencing.

The study of emotions in linguistics has been conducted for a long time; emotions are one of the most difficult objects for understanding and conceptualization in language. Being a more ancient form of the reflection of reality than mediated by the speech cognitive processes, emotions are specific criteria of positive or negative perception of the world. Emotional states being an integral part of any culture pretend to universality that is expressed in defining basic or main types of emotions that are mentioned in the studies of the famous scientists - psychologists and linguists ${ }^{15}$.

\footnotetext{
${ }^{15}$ Diller H. J. Emotions and the Linguistics of English. Tuebingen: Niemeier, 1992. 155 p.
} 
At the same time emotions have some specific features for each nation. The cultural peculiarities of expressing emotions also manifest themselves in the fact that even universal emotions, explicable in different cultures, are evaluated and understood by their representatives differently.

In the study of emotion as a category of linguistics, one must take into account the peculiarities of text semantics, as well as the nature of human emotions, the most important properties of which are their objectivity (orientation to the world) and subjectivity (belonging to the subject). That is why the conceptual modeling of emotionality considers the referential, intentional and receptive aspects of the text, which distinguished the three components of emotionality:

- objectivity as the presence in the text of text of emotional knowledge;

- involvement, embodiment of the author's emotional intentions in the text;

- suggestiveness as an indication of the reader's likely emotional response to a textual reality.

In linguistics there is no complete and unambiguous definition of the concept of emotionality. V. Shakhovskyi defines emotionality as an inherently semantic quality of expressing the system of his means of emotionality as an act of the psyche, reflected in the semantics of linguistic units, social and individual emotions ${ }^{16}$. The researcher also notes that emotionality in the linguistic sense is the sensual evaluation of an object, the expression by linguistic or speech means of feelings, moods, experiences of a person. Emotionality is always expressive and evaluative, but not the other way around.

O. Selivanova understands the emotional component of modern linguistic science as a component of the connotative component in the semantic structure of the linguistic unit, which represents the emotional attitude of native speakers to the designated one. Emotionality can also be formed by denotation of the meaning of the word, which creates a contradiction in the consideration of denotation and connotation within the established boundaries between them ${ }^{17}$.

Modern researchers note that emotionality is also a textual category subordinated to informativeness or modality, which expresses the emotional attitude of the addressee (author), his function in the text, the

\footnotetext{
${ }^{16}$ Шаховский В.И. О лингвистике эмоций // Язык и эмоции. Волгоград: Перемена. 1995. 464 с.

${ }^{17}$ Селіванова О. Сучасна лінгвістика: напрями та проблеми : підручник. Полтава: ДовкілляK, 2008. 711 c.
} 
actors, the likelihood of emotions real or simulated by the author's consciousness of the hypothetical reader, characters, their behavior, and is analyzed using emotionally charged text components (emotional markers).

In addition, it should be noted that there are words that have emotional potential or, according to V. Chabanenko's definition, words with situational emotional-evaluative content, which emotionality is manifested only in context. According to V. Shakhovskyi, these words are not emotional, but in the course of their functioning, they realize their potential and replenish the reserve of emotional vocabulary. V. Shakhovskyi considers the "emotive" as a linguistic unit whose main function is to "express the emotion of the speaker, that is, if its ability is the same for both the sender and the recipient of the language reflected in the emotional aspect of its lexical meaning (that is, in his connotation), and if when replacing this unit with a synonym, the emotionality of the information disappears. He also introduced the scientific concept of emoseme, the essence of which is revealed as a separate kind of family, which correlates with the emotions of the speaker. These semes are expressed in the semantics of the word as the set of the semantic sign "emotion" and concepts of "love", "neglect", "humiliation" and so on. The emotion seme can reflect the emotional process of any person: the speaker, the listener, or some third party ${ }^{18}$.

The vocabulary of each language contains not only words with emotional and stylistic coloring or with a structural component that allows to express emotions, but also words whose emotional qualities are in potential, and the use of which in a particular context gives the word emotional color, which gives them the ability to influence the recipient of this context.

According to V. Shakhovskyi, evaluation is a necessary component of emotions and it is always emotional V. Chabanenko, who considers the expression of emotions in language as a form of expression of social evaluations, holds the same opinion ${ }^{19}$.

It is another matter that the principles for the classification of emotions have not yet been elaborated, and therefore their typology has not been established neither common language nor interlingual. "The principle of assigning a word to the category of emotional is based mainly on a purely external feature not a formal one: if a word expresses or can express, in other words, it can be used to express typed emotions,

\footnotetext{
${ }^{18}$ Шаховский В.И. Проблема разграничения экспрессивности и эмотивности как семантической категории лингвостилистики // Проблемы семасиологии и лингвостилистики. 1975. Вип. 2. С. 3-26.

${ }^{19}$ Чабаненко В.А. Основи мовної експресії. Київ: Вища школа, 1984. 168 с.
} 
then it is emotional". It should be added that the emotive also causes emotions, that is, it has two sides:

a) the side of the speaker (expressing emotions);

b) the side of the perceiver (evoking emotions).

Emotional text means an expression that is formulated in one or more sentences, and "transmits, along with optional and emotional information, with at least one emotional means - linguistic or paralinguistic (kinetic, phonation), which expresses a certain emotion, more or less adequately all communicators in this situation"20.

From this it follows that the emotionality of artistic text as one of the basic properties of artistic text, correlates with the subjected in it emotional knowledge and actualized through emotionally loaded text components that embody the author's emotional intentions and simulate the likely emotions of the addressee, related of reality. V. Shakhovsky distinguishes linguistic and non-linguistic components of emotional text. He includes "emotional vocabulary, phraseology, set emotive designs, emotional" kineme"and" prosode" in their lexical meaning to the first group." And the emotional situation, which includes "emotional supposition, emotional intentions, emotional positions of the communicants at the moment of communication and their common emotional mood", refers to the non-linguistic component. "All this is formally expressed in special means: prosody and kinesics, vocabulary and syntax, structure and stylistics, which act as signals of emotional information of this text"21.

The emotionality of the text has two sides: a content plan and an expression plan. Content is emotionally distributed over the main levels of the text: on the one hand, it is in the form of an emotive element in the cognitive content of the text, and on the other, it is an emotional part of the author's pragmatic strategies. In terms of expression, emotionality is linear and represented in the text by a set of linguistic and text markers of emotions motivated by multilevel emotional content. Functionalsemantic category of emotionality in the text can be represented as a complex of differentiated concepts that reflect its content and form: emotional background, emotional tonality, emotional coloring. Features of emotional background and emotional tone determine the specific emotional content of different types of text and are reflected in the nature of emotional coloring.

\footnotetext{
${ }^{20}$ Johnson-Laird P. The communicative theory of emotions. Oxford: Blackwell, 1988. 97 p.

${ }^{21}$ Шаховский В.И. Эмотивный компонент значения и методы его описания. Учебное пособие к спецкурсу. Волгоград: Перемена. 1983. 96 с.
} 
Emotionality, as the linguistic correlate of the psychological category of emotionality, is an integral property of texts of different types: it is inherent in the texts of all the main functional styles - scientific, officialbusiness, journalistic and artistic. Emotive texts specificity can be determined through the ratio emotional background emotive tone and emotive color and functionally regulated stylistic norms.

Emotional background correlates with a select number of text topics related to emotional situations and potentially emotive for carriers of the culture. These themes can be identified as emotemy. Three types of situations can serve as a source of emotions; a) pre-eminently emotional situations; b) situations based on the "not norm" category; c) situations that explicate emotional states. Emotional tone as a text category is defined as "the kind of subjective modality in the text, which manifests itself in the expression of emotional attitude to the facts of language and refers to the psychological level of text analysis"22.

The language has a close relationship between the intellectual and emotional, the expression of the emotional setting is not limited to a special layer of expressive vocabulary. In a functionally pragmatic approach to the study of emotion, it must be borne in mind that it permeates all the content components of the text.

Sources of emotionality of the text are diverse and not all researchers understand the same. On the one hand, the main source of emotionality in the text is emotional language. The ways of manifesting emotional situations in artistic text are varied: "from collapsed (family specifier, word) and minimally expanded (phrase, sentence) to maximally expanded (text fragment, text)".

Adhering to the communicative approach to the study of emotionality, V. Maslova considers that the most important source of emotionality of the text is its content. According to the researcher, "the content of the text is potentially emotional, because there will always be a recipient for whom it will prove personally meaningful. The emotional content of the text is, after all, the emotional fragments of the world reflected in the text"23. The set of emotions in the text is a kind of dynamic multiplicity that changes as the story progresses. Emotions reflect the inner world of the character in different conditions, in relation to other characters. The removal of emotional vocabulary from the text

\footnotetext{
${ }^{22}$ Белова А. Д. Лингвистические аспекты аргументации / Белова А. Д. - К. : Изд-во СП «Компьютер Норд», 1997. - 300 с.

${ }_{23}^{23}$ Маслова В. Лингвистический анализ экспрессивности художественного текста. Минск: Высшая школа, 1997. 135 с.
} 
and exploring it in isolation from the text can give only a superficial idea of the set of emotional contents that are realized in the text in their uniformity or differentness, monotony or multi differentness.

The main difficulty in dealing with the emotional component of a text is the multidimensional consideration of the emotionality of the text. Emotions characterize all components of a communicative situation, information about which is presented in a "packed" form in the text. On the one hand, emotional text is one type of text that has its own substantive and structural features. As such, emotionality is understood as the emotionality of the text and is considered in the context of such meaningful characteristics as thematic structure, modality, tonality, and evaluation. On the other hand, emotionality is a condition for the realization of the text, since the emotional sphere of a person's personality is a motivating force, directing and regulating cognitive processes and the process of reflection itself. This fact, proven by psychologists, allows the identification of meaningful units and semantic dominants in the text to be guided by the motivational sphere of personality consciousness.

The complexity of studying the phenomenon of textual emotionality in linguistics determines the existence of various approaches to it. Each approach develops its own concepts of textual emotionality, uses its own terminology and research methods, which complicates the understanding of the phenomenon under study.

\section{CONCLUSIONS}

The study of scientific literature shows that quite a few researchers draw a parallel between the emotional and expressive functions of language. Valuation has been found to be a necessary element of emotion, and the same word in different speech situations can express either emotion or emotion and evaluation at the same time.

The emotional component is always evaluative, but if the word is evaluative, it must not necessarily be emotional. The terminological inconsistency in the system of the nominative means of emotion is directly related to the different approaches to the study of this category. Emotionality is a reflection of an individual's emotional state and directly correlates with expressiveness and appreciation, which are integral parts of the semantics of a word, which are often combined in different combinations within its structure. 
Expressiveness has to do with the human property of enhancing the expressiveness and influential power of one's expression. Expressiveness as a quality of human speech is actualized by those linguistic units that have the ability / or are capable of enhancing logical and emotional content, thus acting as a means of subjective expression of the language.

Expression is created by meaningful "impurities" in the word and the appearance of evaluation-characteristic elements. These layers are expressed through word-forming elements, primarily suffixes. The concept of meaning does not directly appraise or relate to the subject, but they seem to accompany it due to the fact that the linguistic unit is used in contexts, spheres of appraisal of meaning.

Expressiveness is always communicative and pragmatic, as it affects the recipient and causes it to reverse. It aims to enhance the impact of the text on the reader, addressing, above all, the emotional aspect of his psyche, and influences the reader's attitude to the text and its understanding.

Expressiveness is often equated with emotionality, although these are different concepts. Emotionality is not always expressive, it can have a neutral expression, and expressiveness is generated not only by emotions, but also by thinking, intelligence, willpower, ethics and aesthetics, specific worldview of speakers. Therefore expressiveness is much broader notion of emotion and can cover all linguistic expression, not just emotional areas of life. Due to the fact that the term "expression" is used in the language, expression (and expressiveness) is perceived as an intense expression that, in the background of the general, neutral, distinguishes individual language units.

\section{SUMMARY}

The article deals with the study of expressiveness and emotionality in Modern Linguistics. It presents the approach to summarize all the tendencies and paradigms in the investigation of expressiveness and emotionality. The methodology of the research is based on the anthropocentric principle, one of the main features of the communicative linguistics, as well as the application of discourse analysis. The specific features of expressiveness and emotionality are analyzed and their qualifying characteristics are strictly marked in the article. 


\section{REFERENCES}

1. Fairclough N. Discourse and text: linguistic and intertextual analysis within discourse analysis // Discourse and Society. 1992. № 3. P. 192-217.

2. Балли Ш. Французская стилистика. Москва: Издательство иностранной литературы, 1961. 393 с.

3. Бахтин М. М. Эстетика словесного творчества / М. М. Бахтин. М. : Искусство, 1986. 445 с.

4. Хоменко Г. Є. Експресивні засоби лексико-семантичного рівня інформаційного тексту // Філологічні студії. 2012. № 8. С. 276-282.

5. Halliday M. A., Hasan R. Language, context and text: aspects of language in a social-semiotic perspective. Oxford: Oxford University Press, 1991. $264 \mathrm{p}$.

6. Wierzbicka A. Emotions across languages and cultures: Diversity and universals. Cambridge: Cambridge University Press, 1999. 187 p.

7. Diller H. J. Emotions and the Linguistics of English. Tuebingen: Niemeier, 1992. 155 p.

8. Miller G. A. Language and communication. New York: Cambridge University Press, 1951. 214 p.

9. Лукьянова Н. А. Экспрессивность как семантическая категория / Н. А. Лукьянова // Языковые категории в лексикологии и синтаксисе. Новосибирск, 1991. С. 46-62.

10. Мацько Л.І. та ін. Стилістика української мови. - К.: Вища шк., 2003.

11. Телия В. Н. Экспрессивность как проявление субъективного фактора в языке и ее прагматическая ориентация / В. Н. Телия. // Человеческий фактор в языке. Языковые механизмы экспрессивности. М. : Наука, 1991. С. 5-34.

12. Шаховский В. И. Эмотивный компонент значения и методы его описания / В. И. Шаховский. Волгоград : ВГПИ, 1983. 94 с.

13. Чабаненко В.А. Стилістика експресивних засобів української мови. Запоріжжя: ЗДУ, 2002. 351 с.

14. Чабаненко В.А. Основи мовної експресії. Київ: Вища школа, 1984. $168 \mathrm{c}$.

15. Diller H. J. Emotions and the Linguistics of English. Tuebingen: Niemeier, 1992. 155 p.

16. Шаховский В.И. О лингвистике эмоций // Язык и эмоции. Волгоград: Перемена. 1995. 464 с. 
17. Селіванова О. Сучасна лінгвістика: напрями та проблеми : підручник. Полтава: Довкілля-К, 2008. 711 с.

18. Шаховский В.И. Проблема разграничения экспрессивности и эмотивности как семантической категории лингвостилистики // Проблемы семасиологии и лингвостилистики. 1975. Вип. 2. С. 3-26.

19. Чабаненко В.А. Основи мовної експресії. Київ: Вища школа, $1984.168 \mathrm{c}$.

20. Johnson-Laird P. The communicative theory of emotions. Oxford: Blackwell, 1988. 97 p.

21. Шаховский В.И. Эмотивный компонент значения и методы его описания. Учебное пособие к спецкурсу. Волгоград: Перемена. $1983.96 \mathrm{c}$.

22. Белова А. Д. Лингвистические аспекты аргументации / Белова А. Д. К. : Изд-во СП «Компьютер Норд», 1997. 300 с.

23. Маслова В. Лингвистический анализ экспрессивности художественного текста. Минск: Высшая школа, 1997. 135 с.

\section{Information about the author:} Melko Kh. B., Candidate of Philology, Associate Professor at the Korunets Department of English and German Philology and Translation

School of Translation Studies Of Kyiv National Linguistic University 35, Boholiubova str., Sofiivska Borshchahivka, 08137, Ukraine 